\title{
Analysis of Bone Mineral Profile After Prolonged Every-Other-Day Feeding in C57BL/6J Male and Female Mice
}

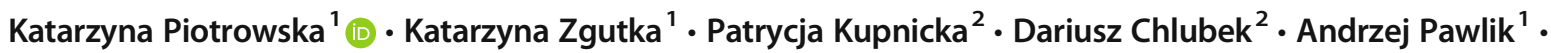 \\ Irena Baranowska-Bosiacka ${ }^{2}$
}

Received: 4 February 2019 / Accepted: 21 May 2019 / Published online: 8 June 2019

(C) The Author(s) 2019

\begin{abstract}
Intermitted fasting or every-other-day feeding (EOD) has many positive effects in rodents and humans. Our goal was to describe how EOD influences bone mineral composition in female and male mice under prolonged EOD feeding. Male and female adult mice were fed EOD for 9 months. After this time, we used a direct method of measurement of mineral components in ashes of long bones (humerus and radius) to estimate the content of calcium $(\mathrm{Ca})$, phosphorus $(\mathrm{P})$, potassium $(\mathrm{K})$, magnesium $(\mathrm{Mg})$, and sodium (Na). We also performed histological analysis of sections of long bones. We found no significant changes in mineral composition between ad libitum and EOD fed males and females. We noted higher $\mathrm{Ca}$ and $\mathrm{P}$ contents in control males vs. females and lower content of $\mathrm{Mg}$ in control males vs. females. We observed the presence of marrow adipose tissue (MAT) in sections of EOD-fed females. EOD without supplementation during feeding days did not increase loss of mineral content of bones in C57BL/6J mice, but the presence of MAT only in EOD females indicates a gender-dependent response to EOD treatment in C57BL/6J mice.
\end{abstract}

Keywords Bone mineral profile $\cdot$ Every-other-day feeding $\cdot$ Caloric restriction $\cdot$ Gender difference

\section{Introduction}

A positive relationship between caloric restriction and longevity has been reported in many species including rodents and humans $[1,2]$. The reduction of food intake without nutrient deficiency may be achieved by different feeding regimes. One of them is reduced calorie consumption in every-day diet. This caloric restriction may vary from $10 \%$ up to $50 \%$ reduction as compared to ad libitum (AL) [3-5]. Moreover, there is known other variant of dietary intervention: every-other-day feeding (EOD) also known as intermitted fasting (IF). This model is based on the principle of feeding ad libitum only every-otherday [6-8]. Intermitted fasting intervention was confirmed to have beneficial effects such as glucose level and glucose tolerance, insulin level, and reduced insulin sensitivity in rodents

Katarzyna Piotrowska

piot.kata@gmail.com; katarzyna.piotrowska@pum.edu

1 Department of Physiology, Pomeranian Medical University in Szczecin, al. Powstańców Wielkopolskich 72, 70-111 Szczecin, Poland

2 Department of Biochemistry, Pomeranian Medical University in Szczecin, al. Powstańców Wielkopolskich 72,

70-111 Szczecin, Poland and humans $[8,9]$. It has been also demonstrated that EOD model helps to reduce weight and increase lifespan in rodents and humans [8-10].

The influence of caloric restriction on bone thickness, density, volume, and resistance was already described for rodents [11-13]. Develin et al., in experiments with juvenile rats, showed that caloric restriction led to decreased bone length and trabecular bone volume, lower resistance to bending or torsion, and deceased number of osteoblasts [11]. It was also shown that decreased body weight decreases bone density in older rats and increased body mass after high-fat diet, which also negatively impacts microstructure of bones in female rats $[12,13]$. Additionally, energy restriction in obese female rats does not improve bone quality [13]. There are not much data showing the impact of energy restriction on bone mineral content established by direct measurement of calcium $(\mathrm{Ca})$ and phosphorus $(\mathrm{P})$ content in bones in long-term feeding experiments in rodents. Inbred strains of mice vary in bone mineral density. C57BL/6J mice were found to have low mineral bone density, with a broad bone marrow cavity, resistant to ovariectomy-induced bone loss, and sensitive to mechanical loading [14-17].

The aim of the present study was to show the influence of an every-other-day feeding regime on mineral content in long bones of low mineral density female and male $\mathrm{C} 57 \mathrm{BL} / 6 \mathrm{~J}$ mice. 


\section{Materials and Methods}

Animals A total of 24, 4-week-old C57BlL/6J mice of both sexes were employed in our experiments. Number of animals used was reduced according to $3 \mathrm{R}$ guideline of Ethical Committee. All animals were purchased from Center of Experimental Medicine, Medical University in Białystok. Mice were randomly divided into two groups (six animals/ group of each sex) and individually housed under a 12:12 light/dark cycle with free access to water. One half of the mice (control) were given uninhibited access to the gain Labofeed $\mathrm{H}$ (containing net energy $12.8 \mathrm{MJ} / \mathrm{kg}$ in proportion: $60 \%$ carbohydrates, $30 \%$ proteins, $10 \%$ fat mineral ingredients in Table 1) (Morawski, Poland), and the other half of the animals were deprived of food and fed AL only every-other-day (EOD) [8]. Body weight was measured once a week starting on day 0 . After 9 months, the mice were sacrificed for bones (humerus and radius) collection. All procedures were approved by the animal care and use Local Ethical Committee of Animal Studies, West Pomeranian University of Technology (no 27/2012).

Tissue Preparation Bones for histological analysis were fixed in $10 \%$ buffered formalin for $24 \mathrm{~h}$, and after fixation, decalcified in $10 \%$ EDTA. After decalcification, soft bones (humerus and radius) were dehydrated and embedded in separate paraffin blocks and cut into $3-\mu \mathrm{m}$ sections. Bones for mineral content analysis were frozen in liquid nitrogen during necropsy and stored at $-80^{\circ} \mathrm{C}$ until analysis.

Histological Analysis Deparaffinized sections of bones $(3 \mu \mathrm{m}$ thick) were rehydrated and stained with Mayer's hematoxylin and eosin (H\&E) stain according to standard procedures. After staining, sections were dehydrated in $95 \%$ and $99.8 \%$ alcohol, cleared with xylene, mounted with Canada balsam (all purchased from Sigma-Aldrich, USA) mounting medium, and evaluated under an Olympus IX81 inverted microscope (Olympus, Germany). Micrographs were collected with CellSens software (Olympus, Germany). Humerus and radius from each animal were evaluated separately. Figure 1 shows exemplary images of histological sections of bones (male radius, female humerus).

Table 1 Amount of mineral ingredients in Labofeed $\mathrm{H}$ chow (commercial diet for maintenance of adult rodents) expressed in $\mathrm{g}$ per $\mathrm{kg}$ of chow

\begin{tabular}{ll}
\hline Ingredient & Amount in $[\mathrm{g} / \mathrm{kg}]$ of chow \\
\hline $\mathrm{K}$ & 9.5 \\
$\mathrm{Ca}$ & 9.5 \\
$\mathrm{P}$ & 7.5 \\
$\mathrm{Mg}$ & 2.9 \\
$\mathrm{Na}$ & 2.0 \\
\hline
\end{tabular}

Bone Mineral Content Analysis All bones were cleaned of excess flesh, tendons, and ligaments, transferred into 1.5-mLmicrotubes, and stored at $-80{ }^{\circ} \mathrm{C}$ until processed.

Samples were analyzed using inductively coupled plasma optical emission spectrometry (ICP-OES, ICAP 7400 Duo, Thermo Scientific) equipped with a concentric nebulizer and cyclonic spray chamber to determine their $\mathrm{Ca}, \mathrm{Mg}, \mathrm{Na}, \mathrm{K}$, and $\mathrm{P}$ contents. Analysis was performed in radial mode.

Samples were thawed at room temperature and dried overnight at $70^{\circ} \mathrm{C}$ to constant weight after cleaning of all adherent tissue. Bones were ground into powder in a porcelain mortar and mineralized using microwave digestion system MARS 5, CEM. The weight of the bone tissue used for analysis was at least $0.052 \mathrm{~g}$.

Samples were transferred to clean polypropylene tubes. One milliliter of $65 \% \mathrm{HNO}_{3}$ (Suprapur, Merck) was added to each vial, and each sample was allowed a 30-min pre-reaction time in the clean hood. After completion of the prereaction time, $1 \mathrm{~mL}$ of non-stabilized $30 \% \mathrm{H}_{2} \mathrm{O}_{2}$ solution (Suprapur, Merck) was added to each vial. Once the addition of all reagents was complete, samples were placed in special Teflon vessels and heated in microwaved digestion system for $35 \mathrm{~min}$ at $180^{\circ} \mathrm{C}\left(15\right.$-min ramp to $180^{\circ} \mathrm{C}$ and maintained at $180^{\circ} \mathrm{C}$ for $20 \mathrm{~min}$ ). At the end of digestion, all samples were removed from the microwave and allowed to cool to room temperature. In the clean hood, samples were transferred to acid-washed $15-\mathrm{mL}$ polypropylene sample tubes. A further 100 -fold dilution was performed prior to ICP-OES measurement. A volume of $100 \mu \mathrm{L}$ was taken from each digest. Samples were spiked with an internal standard to provide a final concentration of $0.5 \mathrm{mg} / \mathrm{L}$ Ytrium in $1 \mathrm{~mL}$ of $1 \%$ Triton (Triton X-100, Sigma) and diluted to the final volume of $10 \mathrm{~mL}$ with $0.075 \%$ nitric acid (Suprapur, Merck). Samples were stored in a monitored refrigerator at a nominal temperature of $8{ }^{\circ} \mathrm{C}$ until analysis.

Blank samples were prepared by adding concentrated nitric acid to tubes without sample and subsequently treated in the same manner as described above for samples.

Multi-element calibration standards (ICP multi-element standard solution IV, Merck for $\mathrm{Ca}, \mathrm{K}, \mathrm{Mg}$, and $\mathrm{Na}$; ICAP 6000 Multi-Element Test Solution, Thermo Scientific for P) were prepared with different concentrations of inorganic elements in the same manner as in blanks and samples.

Deionized water (Direct Q UV, Millipore, approximately 18.0 M $\Omega$ ) was used for preparation of all solutions. The wavelengths $(\mathrm{nm})$ were $315.887(\mathrm{Ca}), 766.490(\mathrm{~K}), 279.553(\mathrm{Mg})$, $589.592(\mathrm{Na})$, and $178.766(\mathrm{P})$. The limits of detections (LOD) for $\mathrm{Ca}, \mathrm{K}, \mathrm{Mg}, \mathrm{Na}$, and $\mathrm{P}$ were $0.017,0.068,0.001$, 0.086 , and $0.008 \mathrm{mg} / \mathrm{L}$, respectively. The concentrations of elements were expressed as $\mathrm{g} / \mathrm{kg}$ dry mass $(\mathrm{dm})$ of bones.

Validation of Analytical Proceedings The accuracy of the analytical procedure was monitored by the determination of the 
Fig. 1 Morphology of bones (H\&E) C57BL/6J mice: males and females. AL, ad libitum fed; EOD, every-other-day-fed animals; objective magnification $\times 10$, scale bar $100 \mu \mathrm{m}$; insert in EOD female panel indicates presence of MAT (marrow adipose tissue) — black arrow; green arrows - macrophages containing hemosiderin; yellow asterisk - collagen fibers; M,- megacariocytes

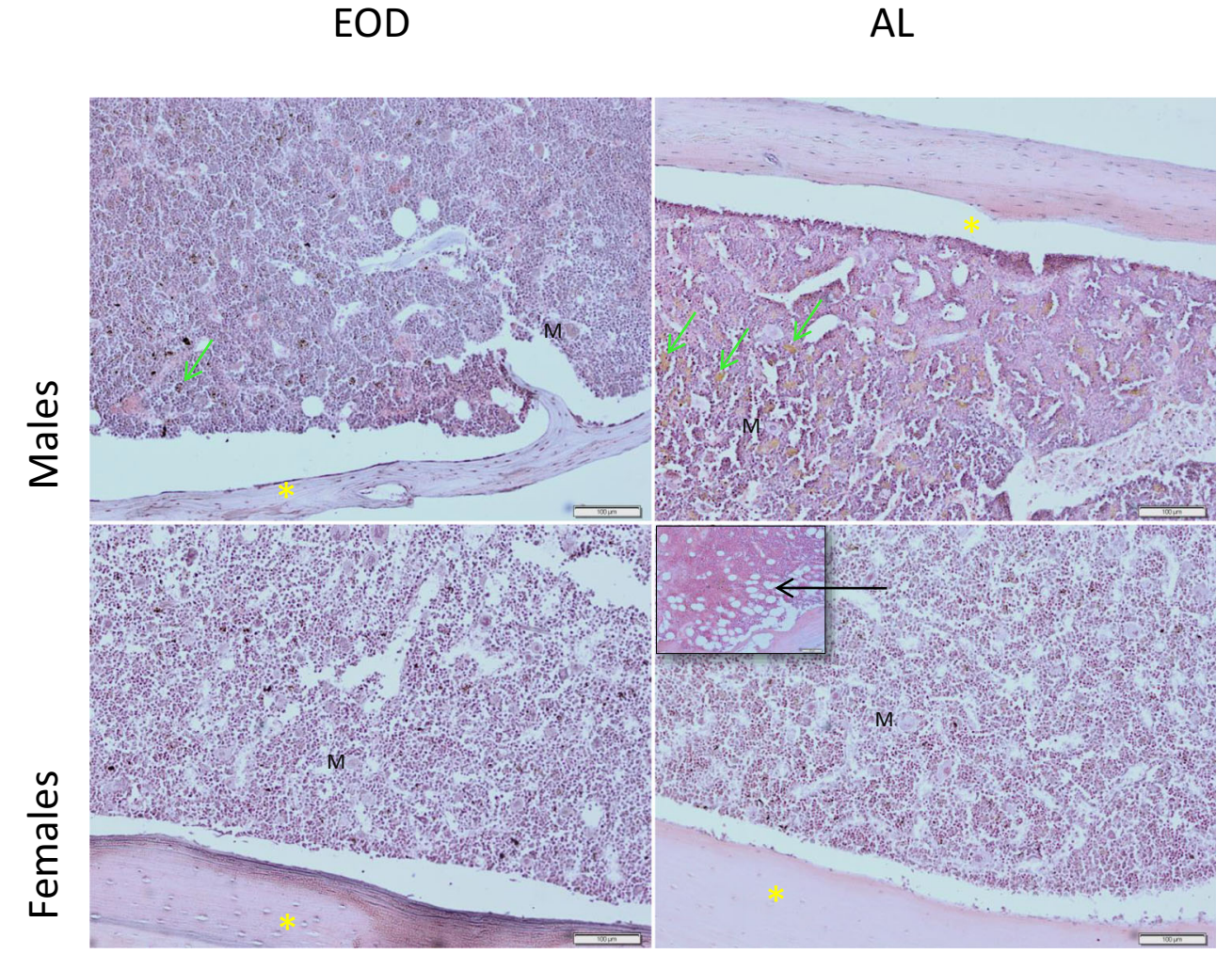

studied elements in reference material: NIST SRM 1486 Bone Meal (National Institute of Standards and Technology). The concentration values of the reference materials given by the manufacturers and our determinations are shown in Table 2. In order to determine the possible loss of analyte during the chemical process or the impact of other factors on the results of research, we conducted recovery testing.

Statistical Analysis The obtained results were analyzed using the Statistica 10.0 software package. Arithmetical mean \pm SD was calculated for each of the studied parameters. The distribution of results for individual variables was obtained with the Shapiro-Wilk W test. As most of the distributions deviated from the normal distribution, non-parametric tests were used for further analyses. To assess the differences between the studied groups, the non-parametric Mann-Whitney $U$-test was used and $p \leq 0.05$ was considered as statistically significant.

Table 2 The analysis of NIST-SRM 1486 (Bone Meal) by ICP-OES

\begin{tabular}{lccc}
\hline \multirow{2}{*}{ Chemical elements } & \multicolumn{2}{c}{ Bone meal SRM NIST 1486 } & \multirow{2}{*}{ Recovery (\%) } \\
\cline { 2 - 3 } & Certified & Measured & \\
\hline $\mathrm{Ca}$ & $265.8 \pm 4$ & $261.7 \pm 22.4$ & 100.49 \\
$\mathrm{~K}$ & $0.412 \pm 4$ & $0.410 \pm 8.6$ & 100.48 \\
$\mathrm{Mg}$ & $4.66 \pm 0.17$ & $4.50 \pm 0.3$ & 95.74 \\
$\mathrm{Na}$ & $5.40 \pm 0.00$ & $5.00 \pm 0.00$ & 108.00 \\
$\mathrm{P}$ & $123.0 \pm 1.9$ & $125.0 \pm 0.3$ & 101.65 \\
\hline
\end{tabular}

\section{Results}

Bone Histology Bone structure was well developed in all groups of mice, with visible collagen fibers arrangement pointed with yellow asterisk, and lacunae with osteocytes. Osteoblasts and osteoclasts were also visible without signs of osteoclasts activation. In broad bone cavities, red bone marrow (RBM) was visible with a high number of megakaryocytes (M). In EOD animals, males had higher numbers of hemosiderin (iron) containing macrophages visible, pointed with green arrows. In bones of two of six EOD females, we found some adipocytes in RBM (insert) (Fig. 1).

Mineral Content of Bones We found higher contents of $\mathrm{Ca}, \mathrm{P}$, and $\mathrm{Na}$ in long bones of EOD females in comparison to ALfed females, but the difference was statistically insignificant. We found changed $\mathrm{Ca}: \mathrm{P}$ ratio. In proper hydroxyapatite crystals Ca:P ratio is 1.667 [18]. In our bone samples, $\mathrm{Ca}: \mathrm{P}$ ratio was: for $\mathrm{Al}$ males 1.141, for $\mathrm{AL}$ females 1.232, for EOD males 1.119, for EOD females 1.183. In all studied groups $\mathrm{Ca}: \mathrm{P}$ ratio shows increased amount of $\mathrm{P}$ and decreased amount of $\mathrm{Ca}$ when compared to stehiometric hydroxyapatite ratio. Levels of $\mathrm{K}$ and $\mathrm{Mg}$ were decreased in EOD females as compared to AL females (Table 3). The proportion between $\mathrm{Ca}$ and $\mathrm{Na}$ was constant and equaled 16:1. In males, we observed similar, but not significant, higher contents of $\mathrm{Ca}$ and $\mathrm{P}$, decreases in $\mathrm{Na}$ and $\mathrm{Mg}$, but a significant increase in potassium (K) content in long bones of EOD males in comparison to AL- 
fed male mice (Table 3). The proportion between $\mathrm{Ca}$ and $\mathrm{Na}$ equaled 21:1 in AL males and 22:1 in EOD males (Table 3).

We also compared the contents of minerals in long bones between control (AL fed) males and females to note any gender differences in mineral content at 10 months of age, which is described as the beginning of osteopenia in male mice. We found significantly higher contents of $\mathrm{Ca}(p<0.05)$ and $\mathrm{P}$ $(p<0.01)$ in AL males vs. AL females, and a significantly $(p<0.01)$ lower content of $\mathrm{Mg}$ in $\mathrm{AL}$ males than females (Table 2). Sodium (Na) and potassium (K) levels were similar in both AL-fed groups (Table 4).

We found no correlation between body weight and amount of $\mathrm{Ca}, \mathrm{P}, \mathrm{K}, \mathrm{Mg}$, and $\mathrm{Na}$ in non-tested groups of animals.

\section{Discussion}

Studied elements play a key role in many cellular processes including cell-signaling, neural processes, muscle function, blood coagulation, acid-base balance, and bone mineralization [20]. Phosphorus is also responsible for proper vascularization and mineralization of hypertrophic chondrocytes in growth plate, which further promotes new bone formation [20]. The majority of $\mathrm{Ca}$ and $\mathrm{P}$ is found in bones or bones and teeth: 99\% and $85 \%$ respectively. In skeleton, $\mathrm{Ca}$ and $\mathrm{P}$ make hydroxyapatite crystal also in the form of calcium phosphate [20]. Minerals can be mobilized from bone to maintain systemic mineral homeostasis even if that leads to loss of structural integrity in skeleton [20].

Experiments on age-related bone loss revealed that femoral bones of C57BL/6J mice increase in length up to 12 weeks of age and bone volume and trabecular number increases until 2 months of age [21, 22]. After that time, bone parameters decline, with greater loss in females than males [21]. The first signs of osteopenia are observed at 42 weeks of age in male mice [22]. It is supported with findings showing $\mathrm{Ca}$ decline from 200 days of age (about 28th week of age) [23], and up to 3 years of age, levels of $\mathrm{Ca}$ in bones decline $28.2 \%$ in
Table 4 Gender differences in mineral composition in control (AL fed) males and females

\begin{tabular}{lcl}
\hline Mineral component & AL males & AL females \\
\hline $\mathrm{Ca}$ & $135.5 \%^{*}$ & $100 \%$ \\
$\mathrm{P}$ & $146.2 \%^{* *}$ & $100 \%$ \\
$\mathrm{Na}$ & $104.1 \%$ & $100 \%$ \\
$\mathrm{Mg}$ & $86.2 \% \%^{* *}$ & $100 \%$ \\
$\mathrm{~K}$ & $104.8 \%$ & $100 \%$ \\
\hline
\end{tabular}

Females established as $100 \%$. * $p<0.05 ; * * p<0.01$

femoral bones of C57BL/6J mice [23]. In C57BL/6J strain, the cancelous bone is thin with low mineral density; bone cavities filled up with bone marrow are broad [14]. In our study, we observed proper histological structure of long bones, with organized parallel collagen arrangement. We did not observed increased activity of osteoclasts in any studied group. That suggests that changes in amounts of mineral contents are not the result of pathological increase of osteoclast activity or decreased collagen synthesis performed by osteoblasts. We observed big cavities with bone marrow. In two slides from EOD females, we noted the presence of adipocytes, often referred to as marrow adipose tissue (MAT) [24]. MAT may comprise up to $70 \%$ of bone marrow [25]. In mice, adipocytes in bone marrow appear in aging animals, but also during caloric restriction (CR) [26]. In our study, we found MAT expansion only in females, which is consistent with other studies [26]. The authors conclude that response to $\mathrm{CR}$ is sex-specific in $\mathrm{C} 57 \mathrm{BL} / 6 \mathrm{~J}$ mice [26]. It also supports our previous data with genderspecific response to EOD in the liver [19].

We previously showed that prolonged EOD causes decreased body mass gain in EOD animals in comparison to their ad libitum-fed littermates, but significant only in males [27]. We speculated, that differences in weight gain between genders may be a result of overfeeding EOD females during the feeding time, or different energy homeostasis governed by sex hormones [27]. We observed no correlation between body mass and mineral composition in any group of experimental animals.

Table 3 Amount of minerals $[\mathrm{g} / \mathrm{kg}$ dry mass $(\mathrm{dm})$ of bones $\pm \mathrm{SD}$ ] in long bones (humerus and radius) of $\mathrm{C} 57 \mathrm{BL} / 6 \mathrm{~J}$ mice. AL, ad libitum fed; EOD, every-other-day-fed animals

\begin{tabular}{|c|c|c|c|c|}
\hline \multirow[b]{2}{*}{ Mineral component } & \multicolumn{2}{|l|}{ Males } & \multicolumn{2}{|l|}{ Females } \\
\hline & $\mathrm{AL}$ & EOD & $\mathrm{AL}$ & EOD \\
\hline $\mathrm{Ca}$ & $269,672 \pm 54,150.8$ & $260,142 \pm 50,174.0$ & $199,070.8 \pm 38,005.59$ & $208,044.64 \pm 16,862.37$ \\
\hline $\mathrm{P}$ & $236,307.9 \pm 49,225.6$ & $232,375.7 \pm 42,397.3$ & $161,626.8 \pm 33,470.68$ & $175,872.2 \pm 12,863.5$ \\
\hline $\mathrm{Na}$ & $7285.8 \pm 824.6$ & $6828.2 \pm 890.5$ & $7000.04 \pm 1115.03$ & $7366,534 \pm 696.47$ \\
\hline $\mathrm{Mg}$ & $5109.5 \pm 622.1$ & $4854.6 \pm 442.2$ & $5930.22 \pm 1001.35$ & $5540.53 \pm 870.53$ \\
\hline $\mathrm{K}$ & $4907.3 \pm 1022.3$ & $5434.2 \pm 1288.6$ & $4681.19 \pm 934.66$ & $4489.77 \pm 897.46$ \\
\hline Weight gain [\%] ref. no [19] & $45.81 *$ & $21.2 *$ & 41.85 & 31.57 \\
\hline
\end{tabular}

Body weight gain during the experimental period, difference significant in male mice * $p<0.05$ 
It was already shown that bone mineral composition does not correlate with body weight in mice [15]. The bones C57BL/6J mice characterize with broad marrow cavities and thin cortical bone with low mineral density [15]. We speculate, that low bone density causes resistance to further bone loss in reply to bone loss-inducing factors like low estrogen level [16]. This may suggest that decrease in mineral elements consumption during EOD treatment in adult C57BIL/6J mice is insufficient stimulus to cause bone loss similar to ovariectomy which is also insufficient to induced bone loss in this strain of mice [16].

Calcium $(\mathrm{Ca})$ is a major bone mineral ingredient. The level of $\mathrm{Ca}$ absorption from the gastrointestinal track depends on its content in food-in low Ca content, the intestinal absorption may increase from 33 to $50 \%$ or more $[28,29]$. Absorption is facilitated by active vitamin $\mathrm{D}$ and parathormone ( $\mathrm{PTH})$ and may be reduced by the action of calcitonin or cortisol [29]. The serum levels of $\mathrm{Ca}$ also depend on osteogenic and osteolytic processes in bones, which are also under hormonal control. Phosphates, androgens, oestrogens, and calcitonin increase bone formation, while $\mathrm{PTH}$, vitamin D, prostaglandin E1, and increased levels of thyroid gland hormones activate bone resorption [30, 31].

We also noted disproportion in $\mathrm{Ca}$ and $\mathrm{P}$ contents between males and females of AL groups, which is in with agreement with previous data showing greater loss of bone mineral content in female than male mice [21]. The EOD feeding regime did not significantly influence the amount of $\mathrm{Ca}$ or $\mathrm{P}$ in bone structure when we compared control males vs. EOD males and control females vs. EOD females for single mineral. We observed decreased Ca:P ratio in all studied groups in comparison to stehiometric hydroxyapatite ratio $(\mathrm{Ca}: \mathrm{P}=1.667)$. We suggest that this difference may be the result of the type of bone used in the analysis; we used upper limb bones humerus and radius while other teams usually use tibia and femur [14-17]. Also, the strain and sex of animals used in the study may be the reason of this disproportion: we used low mineral density C57BIL/6J mice and not only males but also females. Additionally, diet, balanced but used every-other-day may be responsible for this disproportion. Decreased mineral content in humerus of C57BL/6J mice after dietary restriction was reported by Murray and coauthors [32]. The type of diet was caloric restriction to $70 \%$ of ad libitum [32]. The increased $\mathrm{P}$ amount after $40 \%$ caloric restriction was also observed in male rats, and this increase of $\mathrm{P}$ was significantly higher in older restricted animals than younger restricted rats [33]. This may suggest that dietary restriction without supplementation, introduced to adult animals, does not intensify bone loss observed during the life span but changes the Ca:P ratio that may suggest delayed bone maturation [33].

In our experiment, increased $\mathrm{K}$ levels were observed in bones of EOD males. On the other hand, the concentration of $\mathrm{K}$ in $\mathrm{AL}$ males was insignificantly higher than in $\mathrm{AL}$ female mice. Potassium $(\mathrm{K})$ in bones is found in interstitial fluid, which surrounds bone crystals and buffers metabolic acid load, preventing bone loss $[34,35]$. The most common reason for increased $\mathrm{K}$ concentration is increased intake. But in our feeding regime, we did not used any supplementation during the fasting or feeding periods. The increased level of $\mathrm{K}$ may partly explain increased $\mathrm{Ca}$ and $\mathrm{P}$ contents in bones, as protection from bone loss. However, bone metabolism is relatively insensitive to potassium imbalance [34, 35]. Macdonald et al. [36] noted that there is no effect of 2-year of potassium citrate supplementation on bone metabolism, turnover, and bone mineral density in post-menopausal women, but in other study, the authors shown that potassium citrate supplementation is beneficial only for women with high dietary sodium chloride intake [37].

The Mg concentration was insignificantly lower in EOD females and males in comparison to AL-fed animals. The skeleton is a main site for $\mathrm{Mg}$ storage (up to $60 \%$ ) and one-third of $\mathrm{Mg}$ is found in the cortical bone [38, 39]. Magnesium antagonizes $\mathrm{Ca}$ [38]. The decreased concentration of Mg during prolonged EOD treatment may be a reason for the observed tendency of increased $\mathrm{Ca}$ concentrations in EOD-fed animals. On the other hand, $\mathrm{Mg}$ concentration was significantly lower in AL-fed males than females, but $\mathrm{Ca}$ concentration was significantly higher in $\mathrm{AL}$ males in comparison to AL-fed females. In our opinion, it supports the hypothesis that bone response to EOD feeding regime is sex-specific. Magnesium plays a crucial role in the activation of enzymes involved in bone turnover [28]. Decreased Mg levels lead to decreased proliferation and development of chondroblasts in cartilage of bones growth plates, which in turn disrupts the synthesis of organic elements of the extracellular matrix and further mineralization of the matrix [28]. The crucial element of $\mathrm{Mg}$ action in bone is the activation of acidic and alkaline phosphatases and other enzymes. Calcium ions inhibit the action of alkaline phosphatase (expressed by mature osteoblasts) [40]. There is also a strong connection between the concentrations of $\mathrm{Ca}, \mathrm{Mg}$, and PTH and their action, which in turn influences bone turnover. Magnesium is localized on the surface of crystals and can be exchanged for $\mathrm{Ca}$ [41]. Disturbances in the $\mathrm{Ca} / \mathrm{Mg}$ ratio may be the cause of the calcification of arteries, muscles or joints, and bone decalcification (osteoporosis) and may lead to nephrolithiasis or adrenal insufficiency [42]. Hypomagnesemia may lead to hypocalcemia even if $\mathrm{Ca}$ intake and excretion is normal [42].

We also established the Na concentration in mice long bones. Sodium is abundant in extracellular fluid in bones, but large amounts of $\mathrm{Na}$ in bone are also found in the apatite complex in calcified material of bone [43]. The Ca:Na molar ratio in bones established for humans, monkeys, cats, dogs, and rats is 30:1 [44]. In our experiment, the Ca:Na molar ratio was16:1 in female mice regardless of diet, 21:1 in AL males, and 22:1 in EOD males. The difference in molar ratio may be a result of age: at the time of mineral concentration measurements mice were middle age (11 months of age). Harrison does not describe the age of animals used in his experiment, but we may conclude that they were young adults, with fully developed skeleton [44]. 
Bone disease is not associated with sodium excessive intake or deficiency but there is growing concern over the impacts of hyponatremia on osteoporosis in the elderly, what was demonstrated in several epidemiologic studies [42, 45]. One of the mechanisms of hyponatremia influence on bone metabolism is stimulation osteoclasts proliferation and activity to mobilize sodium stored in bone [46, 47]. Therefore, high-salt diet should be recommended, but on the other hand, this diet has been shown to increase calcium resorption from bone [47] so people at risk for osteoporosis should be carefully monitored for sodium intakes.

\section{Conclusion}

In a strain of mice characterized with low mineral density of bones, prolonged EOD treatment did not lead to increased mineral loss. EOD feeding routine started in adulthood did not intensify the loss of mineral content with age, but opposite: ameliorated the decrease of mineral deposits in animals with low mineral density. There is a possibility that this effect will be found only in $\mathrm{C} 57 \mathrm{BL} / 6 \mathrm{~J}$ mice, similar to its resistance to ovariectomyinduced bone loss or sensitivity to mechanical loading.

Authors Contributions $\mathrm{K} \mathrm{P}$-designed the experiment, data collection and histological analysis, statistical analysis, and writing and revision of manuscript; K Z - helped in conception and design of the experiment, help in data collection; $\mathrm{PK}$ - helped in data collection; $\mathrm{DC}$ - found collection; $\mathrm{AP}$ found collection; I B-B - drafted and revised the manuscript.

All authors approved final version of manuscript.

Funding Information This study was supported by the statutory budget of the Department of Biochemistry and Medical Chemistry and Physiology Department of Pomeranian Medical University in Szczecin, Poland.

\section{Compliance with Ethical Standards}

Conflict of Interest The authors declare that they have no conflict of interest.

Animal Studies All procedures performed in studies involving animals were in accordance with the ethical standards of the institution or practice at which the studies were conducted.

Open Access This article is distributed under the terms of the Creative Commons Attribution 4.0 International License (http:// creativecommons.org/licenses/by/4.0/), which permits unrestricted use, distribution, and reproduction in any medium, provided you give appropriate credit to the original author(s) and the source, provide a link to the Creative Commons license, and indicate if changes were made.

\section{References}

1. Anisimov VN (2010) Metformin for aging and cancer prevention. Aging 2:760-774. https://doi.org/10.18632/aging.100230

2. Anisimov VN, Zabezhinski MA, Popovich IG, Piskunova TS, Semenchenko AV, Tyndyk ML et al (2010) Rapamycin extends maximal lifespan in cancer-prone mice. Am J Pathol 176:20922097. https://doi.org/10.2353/ajpath.2010.091050

3. Stankovic M, Mladenovic D, Ninkovic M, Vucevic D, Tomasevic T, Radosavljevic T (2013) Effects of caloric restriction on oxidative stress parameters. Gen Physiol Biophys 32:277-283. https://doi. org/10.4149/gpb_2013027

4. Harvey AE, Lashinger LM, Otto G, Nunez NP, Hursting SD (2013) Decreased systemic IGF-1 in response to calorie restriction modulates murine tumor cell growth, nuclear factor $-\mathrm{KB}$ activation, and inflammation-related gene expression. Mol Carcinog 52:997-1006. https://doi.org/10.1002/mc.21940

5. Zhu M, de Cobo R, Anson RM, Ingram DK, Lane MA (2005) Caloric restriction modulates insulin receptor signaling in liver and skeletal muscle of rat. Nutrition 21:378-388. https://doi.org/ 10.1016/j.nut.2004.06.030

6. Zhang LN, Mitchell SE, Hambly C, Morgan DG, Clapham JC, Speakman JR (2012) Physiological and behavioral responses to intermitted starvation in C57BL/6J mice. Physiol Behav 105:376387. https://doi.org/10.1016/j.physbeh.2011.08.035

7. Descamps O, Riondel J, Ducros V, Roussel AM (2005) Mitochondrial production of reactive oxygen species and incidence of age-associated lymphoma in OF1 mice: effect OF alternate-day fasting. Mech Ageing Dev 126:1185-1191. https://doi.org/10. 1016/j.mad.2005.06.007

8. Masternak MM, Al-Regaiey KA, Bonkowski MS, Panici JA, Bartke A (2005) Effect of every other day feeding diet on gene expression in normal and long-lived Ames dwarf mice. Exp Gerontol 40:491-497. https://doi.org/10.1016/j.exger.2005.06.003

9. Soeters MR, Lammers NM, Dubbelhuis PF, Ackermans M, Jonkers-Schuitema CF, Fliers E et al (2009) Intermitted fasting does not affect whole-body glucose, lipid, or protein metabolism. Am J Clin Nutr 90:1244-1251. https://doi.org/10.3945/ajcn.2008.27327

10. Harvie MN, Pegington M, Mattson MP, Frystyk J, Dillon B, Evans $G$ et al (2011) The effects of intermitted or continuous energy restriction on weight loss and metabolic disease risk markers: a randomized trial in young overweight women. Int J Obes 35:714-727. https://doi.org/10.1038/ijo.2010.171

11. Develin MJ, Brooks DJ, Conlon C, Vliet MV, Louis L, Rosen CJ, Bouxsein ML (2016) Daily leptin blunts marrow fat but does not impact bone mass in calorie restricted mice. J Endocrinol 229:295306. https://doi.org/10.1530/JOE-15-0473

12. Talbott SM, Rothkopf MM, Shapses SA (1998) Dietary restriction of energy and calcium alters bone turnover and density in younger and older female rats. J Nutr 128:640-645. https://doi.org/10.1093/ jn/128.3.640

13. Shen CL, Zhu W, Gao W, Wang S, Chen L, Chyn MC (2013) Energy restricted diet benefits body composition but degradates bone integrity in middle-aged obese female rats. Nutr Res 33: 668-676. https://doi.org/10.1016/j.nutres.2013.05.008

14. Richman C, Kutilek S, Miyakoshi N, Srivastava AK, Beamer WG, Donahue LR et al (2001) Postnatal and pubertal skeletal changes contribute predominantly to the difference in peak bone density between $\mathrm{C} 3 \mathrm{H} / \mathrm{HeJ}$ and C57BL/6J mice. J Bone Miner Res 16(2): 386-397. https://doi.org/10.1359/jbmr.2001.16.2.386

15. Beamer WG, Donahue LR, Rosen CJ, Baylink DJ (1996) Genetic variability in adult bone density among inbred strains of mice. Bone 18(5):397-403. https://doi.org/10.1016/8756-3282(96)00047-6

16. Bouxsein ML, Myers KS, Shultz KL, Donahue LR, Rosen CJ, Beamer WG (2005) Ovariectomy- induced bone loss varies among inbred strains of mice. J Bone Miner Res 20(7):1085-1092. https:// doi.org/10.1359/JBMR.050307

17. Kodama Y, Umemura Y, Nagasawa S, Beamer WG, Donahue LR, Rosen CJ et al (2000) Exercise and mechanical loading increase periosteal bone formation and whole bone strength in C57BL/6J mice but not in $\mathrm{C} 3 \mathrm{H} / \mathrm{HeJ}$ mice. Calcif Tissue Int 66(4):298-306 
18. Jarcho M, Bolen CH, Thomas MB, Bobick J, Kay JF, Doremus RH (1976) Hydroxylapatite synthesis and characterization in dense polycrystalline form. J Mater Sci 11:2027-2035. https://doi.org/ 10.1007/BF02403350

19. Piotrowska K, Tarnowski M, Zgutka K, Pawlik A (2016) Gender difference in response to prolonged every-other-day feeding on proliferation and apoptosis of hepatocytes in mice. Nutrients 8: 176. https://doi.org/10.3390/nu8030176

20. Shaker JL, Deftos L Chapter 2: calcium and phosphate homeostasis. In: Singer F (ed) Diseases of bone and mineral metabolism www.endotext.org. Accessed 15 Feb 2018

21. Glatt V, Canalis E, Stadmeyer L, Bouxsein ML (2007) Age-related changes in trabercular architecture differ in female and male C57BL/6J mice. J Bone Miner Res 22(8):1197-1207. https://doi. org/10.1359/jbmr.070507

22. Ferguson VL, Ayers RA, Bateman TA, Simske SJ (2003) Bone development and age-related bone loss in male C57BL/6J mice. Bone 33:387-398. https://doi.org/10.1016/S8756-3282(03)00199-6

23. Massie HR, Aiello VR, DeWolfe LK (1989) Calcium and calmodulin changes with aging in C57BL/6J mice. Gerontology 35:100 105. https://doi.org/10.1159/0002113006

24. Ichijo T, Yamashita Y, Terashima T (1993) Observations on structural features and characteristics of biological apatite crystals. 7. Observation on lattice imperfection of human tooth and bone crystals II. Bull Tokyo Med Dent Univ 40:193-205 http://lib.tmd.ac.jp/ jmd/4003/04_Ichijo.pdf. Accessed 13 March 2018

25. Scheller EL, Rosen CJ (2014) What's the matter with MAT? Marrow adipose tissue, metabolism, and skeletal health. Ann N Y Acad Sci 1311:14-30. https://doi.org/10.1111/nyas. 12327

26. Cawthorn WP, Scheller EL, Parlee SD, An Pham H, Learman BS, Redshaw CMH et al (2016) Expansion of bone marrow adipose tissue during caloric restriction is associated with increased circulating glucocorticoids and not with hypoleptinemia. Endocrinology 157:508-521. https://doi.org/10.1210/en.2015-1477

27. Grymula K, Piotrowska K, Słuczanowska-Głąbowska S, Mierzejewska K, Tarnowski M, Tkacz M, Poniewierska-Baran A, Pędziwiatr D, Suszyńska E, Laszczyńska M, Ratajczak MZ (2014) Positive effect of prolonged caloric restrictionon the population of very small embryonic-like stem cells - hematopoietic and ovarian implications. J Ovarian Res 7:68. https://doi.org/10.1186/17572215-7-68

28. Rude RK, Gruber HE, Wei LY, Frausto A, Mills BG (2003) Magnesium deficiency: effect on bone and mineral metabolism in the mouse. Calcif Tissue Int 72(1):32-41. https://doi.org/10.1007/ s00223-001-1091-1

29. Fleet JC, Schoch RD (2010) Molecular mechanisms for regulation of interstinal calcium absorption by vitamin $\mathrm{D}$ and other factors. Crit Rev Clin Lab Sci 47(4):181-195. https://doi.org/10.3109/ 10408363.2010.536429

30. Arnett T (2003) Regulation of bone cell function by acid-base balance. Prot Nutr Soc 62:511-520. https://doi.org/10.1076/ PNS2003268

31. Sapir-Koren R, Livshits G (2011) Bone mineralization and regulation of phosphate homeostasis. IBMS BoneKey 8(6):286-300. https://doi.org/10.1138/20110516

32. Murray SS, Duarte MEL, Brochmann EJ (2003) The effects of dietary restriction on humeral and mandibular bone in SENCAR, C57BL/6, and DBA/2 mice. Metabolism 52(2):970-977. https:// doi.org/10.1016/S0026-0495(03)00164-1

33. Nnakwe NE (1998) The effect of age and dietary restriction on bone strength, calcium and phosphorus contents of male F344 rats. J Nutr Health Aging 2(3):149-152
34. Tylavsky FA, Spence LA, Harkness L (2008) The importance of calcium, potassium, and acid-base homeostasis in bone health and osteoporosis prevention. J Nutr 138:164S-165S. https://doi.org/10. 1093/jn/136.1.164S

35. Krieger NS, Frick KK, Bushinsky DA (2004) Mechanism of acidinduced bone resorption. Curr Opin Nephrol Hypertens 13:423436. https://doi.org/10.1097/01.mnh.0000133975.32559.6b

36. Macdonald HM, Black AJ, Aucott L, Duthie G, Duthie S, Sandison R, Hardcastle AC, Lanham New SA, Fraser WD, Reid DM (2008) Effect of potassium citrate supplementation or increased fruit and vegetable intake on bone metabolism in healthy postmenopausal women: a randomized controlled trial. Am J Clin Nutr 8:465474. https://doi.org/10.1093/ajen/88.2.465

37. Sellmeyer DE, Schloetter M, Sebastian A (2002) Potassium citrate prevents increased urine calcium excretion and bone resorption induced by high sodium chloride diet. J Clin Endocrinol Metab 87: 2008-2012. https://doi.org/10.1210/jcem.87.5.8470

38. Castiglioni S, Cazzaniga A, Albisetti W, Maier JAM (2013) Magnesium and osteoporosis: current state of knowledge and future research directions. Nutrients 5:3022-3033. https://doi.org/10. 3390/nu5083022

39. Gröber U, Schmidt J, Kisters K (2015) Magnesium in prevention and therapy. Nutrients 7:8199-8226. https://doi.org/10.3390/ nu7095388

40. Leone FA, Ciancaglini P, Pizauro JM (1997) Effect of calcium ions on rat osseous plate alkaline phosphatase activity. J Inorg Biochem 24(6):923-928. https://doi.org/10.1016/S0162-0134(97)00047-0

41. de Baaij JH, Hoenderop JG, Bindels RJ (2015) Magnesiumin man: implications for health and disease. Physiol Rev 95(1):1-46. https:// doi.org/10.1152/physrev.00012.2014

42. Verbalis JG, Barsony J, Sugimura Y, Tian Y, Adams DJ, Carter EA, Resnick HE (2010) Hyponatremia-induced osteoporosis. J Bone Miner Res 25:554-563. https://doi.org/10.1359/jbmr.090827

43. Whang R (1994) Magnesium homeostasis and clinical disorders of magnesium deficiency. Ann Pharmacother 28(2):220-226. https:// doi.org/10.1177/106002809402800213

44. Harrison HE (1937) The sodium content of bone and other calcified material. J Biol Chem 120:457-462 www.bc.org/content/120/2/ 457.full.pdf.Accessed 02 Feb 2018

45. Hoorn EJ, Rivadeneira F, van Meurs JBJ, Ziere G, Stricker BH, Hofman A, Pols HAP, Zietse R, Uitterlinden AG, Zillikens MC (2011) Mild hyponatremia as a risk factor for fractures: the Rotterdam study. J Bone Miner Res 26:1822-1828. https://oi. org/10.1002/jbmr.380

46. Barsony J, Sugimura Y, Verbalis JG (2011) Osteoclast response to low extracellular sodium and the mechanism of hyponatremiainduced bone loss. J Biol Chem 286(12):10864-10875. https:// doi.org/10.1074/jbc.M110.155002

47. Teucher B, Dainty JR, Spinks CA, Majsak-Newman G, Berry DJ, Hoogewerff JA, Foxall RJ, Jakobsen J, Cashman KD, Flynn A, Fairweather-Tait SJ (2008) Sodium and bone health: impact of moderately high and low salt intakes on calcium metabolism in postmenopausal women. J Bone Miner Res 23:1477-1485. https://doi.org/10.1359/jbmr.080408

Publisher's Note Springer Nature remains neutral with regard to jurisdictional claims in published maps and institutional affiliations. 